\title{
Family interview guide: strategy to develop skills in novice nurses
}

\author{
Guia para entrevistas com famílias: estratégia para desenvolver habilidades no enfermeiro novato \\ Guía para entrevistas con familias: estrategia para desarrollar habilidades en el enfermero novato
}

\section{Larissa Guanaes dos Santos', Andréia Cascaes Cruz", Francine Fernandes Pires Mekitarian"', Margareth Angelo'"I \\ 'Universidade de São Paulo, School of Nursing, Nursing Internship Program in Child and Adolescent Health. São Paulo, Brazil. \\ "Universidade Federal de São Paulo, Paulista School of Nursing. São Paulo, Brazil. \\ II' Universidade de São Paulo, School of Nursing, Postgraduate Program in Nursing. São Paulo, Brazil.}

\begin{abstract}
How to cite this article:
Santos LG, Cruz AC, Mekitarian FFP, Angelo M. Family interview guide: strategy to develop skills in novice nurses. Rev Bras Enferm [Internet]. 2017;70(6):1129-36. DOI: http://dx.doi.org/10.1590/0034-7167-2016-0072
\end{abstract}

Submission: 11-21-2016 Approval: 01-18-2017

\begin{abstract}
Objective: describe the skills of nurses to conduct family interviews based on the Family Care Guide for Nursing Clinical Practice. Method: exploratory case study that analyzed the content of 16 guides applied to a child emergency service by a novice nurse from the family nursing area. Results: the records indicated the presence of perceptual, conceptual, and executive skills required to conduct family interviews, in particular skills for the development of genograms, therapeutic relationships, and actions to fulfill family needs. Final considerations: the Family Care Guide for Nursing Clinical Practice is a useful tool to guide the training processes, promote the development of family interview skills in novice nurses, and allow the cognitive consolidation of essential elements of patient- and family-centered care.
\end{abstract}

Descriptors: Family Nursing; Interview; Clinical Competence; Training; Interpersonal Relationships.

\section{RESUMO}

Objetivo: descrever as habilidades do enfermeiro na realização de entrevistas com famílias orientadas pelo Guia de Atendimento às Famílias na Prática Clínica de Enfermagem. Método: estudo de caso com abordagem exploratória do conteúdo de dezesseis guias aplicados em um Pronto Socorro Infantil por enfermeira novata na área de enfermagem da família. Resultados: os registros indicaram a presença de habilidades perceptivas, conceituais e executivas necessárias para a condução de entrevistas com famílias, em especial habilidades relacionadas à elaboração do genograma, estabelecimento de relacionamento terapêutico e realização de ações voltadas ao atendimento das necessidades das famílias. Considerações finais: o Guia de Atendimento às Famílias na Prática Clínica de Enfermagem é uma ferramenta útil para nortear processos de formação, colaborar para o desenvolvimento de habilidades para realização de entrevista com famílias nos enfermeiros novatos e possibilitar a consolidação cognitiva de elementos essenciais para o cuidado centrado no paciente e na família.

Descritores: Enfermagem Familiar; Entrevista; Competência Clínica; Capacitação; Relações Interpessoais.

\section{RESUMEN}

Objetivo: Describir las habilidades del enfermero en la realización de entrevistas con familias orientadas por la Guía de Atención a las Familias en la Práctica Clínica de Enfermería. Método: Estudio de caso con abordaje exploratorio del contenido de dieciséis guías aplicadas en un Pronto Socorro Infantil por enfermera novata en el área de enfermería de la familia. Resultados: Los registros indicaron presencia de habilidades perceptivas, conceptuales y ejecutivas necesarias para conducir entrevistas con familias, particularmente habilidades relacionadas a elaboración del genograma, establecimiento de relación terapéutica y realización de acciones orientadas a atención de necesidades familiares. Consideraciones finales: La Guía de Atención a las Familias en la Práctica Clínica de Enfermería constituye una herramienta útil para orientar procesos de formación, colaborar al 
desarrollo de habilidades para realizar entrevistas con familias en enfermeros novatos y permitir la consolidación cognitiva de elementos esenciales para el cuidado centralizado en el paciente y la familia.

Descriptores: Enfermería de la Familia; Entrevista; Competencia Clínica; Capacitación; Relaciones Interpersonales.

\section{CORRESPNDING AUTHOR Andréia Cascaes Cruz E-mail: deiacascaes@gmail.com}

\section{INTRODUCTION}

The presence of families in healthcare settings has influenced changes in the focus of nursing care, expanding care beyond patients to include families as well. Regarding a children's hospital context, authors report that care is a process of interaction between the family-child and nursing ${ }^{(1-2)}$.

In this sense, the idea of family as caretaker, task manager, information provider, visitor, or companion, is no longer adequate. Family as an actor of care provision includes the patient as well, an active participant in the care process and in the experience of disease and hospitalization.

A Brazilian study showed that the presence of theoretical content on family care in higher education is a reality in the training of nurses working in pediatrics; the study also found that nurses with previous contact with such theoretical knowledge tended to have attitudes supporting the inclusion of families in nursing care $^{(3)}$.

However, promoting family participation in care provision is not the same as being able to provide care to families in clinical settings. Providing care to families in nursing practice requires the acquisition of skills and the development of specific abilities, so that the nurse can perform the assessment and interventions within the family system, fulfilling the demands resulting from the experience of disease and hospitalization.

Regarding the acquisition of clinical competence by nurses, there are five different levels of professional competence: novice; advanced beginner; competent; proficient; and expert. A novice nurse is starting his/her career, has no previous experience or still cannot understand some aspects of his/her practice; this includes all professionals in their first contact with a field and/or specialty in which they had never worked ${ }^{(4)}$.

To work with families, nurses need to present specific skills for the family interview process, which comprises four stages: engagement; assessment; intervention; and conclusion. According to the literature, each stage requires three types of skills-perceptual, conceptual and executive-to effectively conduct all stages of a family interview ${ }^{(5)}$. According to the authors, perceptual skills are related to the nurse's ability to provide important perceptions. Conceptual skills refer to the ability to attribute meanings to what has been observed. Executive skills refer to the interventions performed by a nurse in a family interview ${ }^{(5)}$.

Promoting integration and reducing the gap between nursing theory and clinical practice with families is a challenge, requiring methods and strategies that increase novice nurse self-efficacy and the acquisition of skills and competence for effective, high-quality, and responsive work to fulfill the needs of children, families, the staff, and the health system. Useful strategies for family and nursing teaching are: role model; reflective practice; role play; coaching; and peer mentoring, emphasizing the importance of the mentor as a fundamental element in the acquisition of clinical competence for nursing practice in family care ${ }^{(6)}$.

Aiming to assist novice nurses in their process of developing skills, competence, and a greater sense of self-efficacy for their work conducted with families, an instrument called the Family Care Guide for Nursing Clinical Practice ${ }^{(7)}$ was developed, so that, associated with a process of educational intervention, it could help conduct and record actions of family care for nurses beginning in this field of knowledge.

In view of these facts, this study is guided by the following question: How can the use of an instrument to guide and record family care be useful in the skill acquisition process of a novice nurse conducting family interviews?

Given these considerations, the objective of this study was to describe the nurse's skills in conducting family interviews based on the Family Care Guide for Nursing Clinical Practice.

\section{METHOD}

\section{Ethical aspects}

This study was conducted under a research project approved by the Research Ethics Committee at the School of Nursing of the University of São Paulo, and the Research Ethics Committee at the University Hospital of the University of São Paulo.

\section{Theoretical-methodological framework and study design}

The case study method was used to conduct this investigation, which "analyzes a contemporary phenomenon (the 'case') in detail and in its real world context"(8). This method should be used when the study objective is to explain "how" and/or "why" a particular phenomenon occurs in generally limited contexts. This analysis shows the experiences of individuals involved and situational elements that are essential for the studied problem. The case study method has three different approaches: exploratory; descriptive; and explanatory ${ }^{(8)}$.

This study used the exploratory approach of the Family Care Guide for Nursing Clinical Practice ${ }^{(7)}$, as this approach should be selected when investigating a certain phenomenon with the aim of learning about it and analyzing it, allowing the investigator to become familiar with the studied event, which in turn allows the development of assumptions ${ }^{(8)}$. This method also favors the collection of a large amount of detailed information that enables an understanding of the whole situation; therefore, it was used in this study as it collected information about the identification of skills acquired by the novice nurse to conduct family interviews, using the Guide as a supporting instrument. 


\section{Methodological procedures}

\section{Study setting}

The study setting was the observation sector of the children's emergency service of a university hospital located in the city of São Paulo.

\section{Data collection and organization}

This case study analyzed the records from 16 guides applied between March and May 2015 by one of the study authors (referred to as the novice nurse in this article), previously trained in family care at a university hospital located in the city of São Paulo.

This training was provided by a family nursing expert and comprised theoretical and practical modules, with role play and family care provided in the clinical practice using the Family Care Guide for Nursing Clinical Practice.

The use of the guide in clinical practice of nurses was the last stage of the training and involved its application by the nurses who participated in the educational intervention, as well as its discussion with the expert nurse from the area of family nursing, who acted as a mentor in this learning process $^{(7)}$.

The Family Care Guide for the Nursing Clinical Practice was developed by two of the co-authors of the study, experts in family nursing, based on the Calgary Family Assessment and Intervention Models ${ }^{(5)}$. This instrument has three major segments: Family Assessment; Actions Performed; and Observed/Reached Results.

The segment Family Assessment has fields for: (1) description of the purpose or reason for the family interview; (2) description of family members and staff present during the interview; (3) genogram development; (4) description of: family problems or concerns and strong points of the family and family support/resources, preceded by suggested questions to provide nurses with an understanding of the disease/hospitalization impact on the family; and (5) description of the answers to two questions made to the family aiming to show the main need of the family related to the current disease/ hospitalization condition.

The segment of Actions Performed is structured as a checklist, with prior indication of 10 interventions that cover the cognitive, affective, and behavioral domains that should be checked by the nurse as they are performed. The segment Observed/Reached Results is structurally integrated into the previous segment and has fields for the description of the nurse's perceptions of family reactions after the actions have been performed. The instrument has a field for the nurse to write down other actions not included in the checklist that have been performed or that may help the family, even when not performed by the nurse.

\section{Data analysis}

Each instrument was identified by ordinal numbers, according to the order of interviews. The information recorded in the guides was submitted to a qualitative content analysis, grouped by similarity, with subsequent descriptive analysis and frequency analysis for data presentation. Regarding data treatment and analysis related to the development of skills by the novice nurse, the "development of skills for family nursing interviews"(5) was used for reference, where the actions described as performed by the novice nurse were correlated to the perceptual, conceptual, and executive skills described in the reference material.

\section{RESULTS}

The interviews were conducted and recorded within a mean time of 15 minutes, a maximum time of 20 minutes, and a minimum time of 10 minutes. The interview duration, in relation to the period of the family in the emergency service, varied from 40 minutes to 75 hours, characterizing long periods of the families in the service. The reasons for hospitalization of children aged 14 days to 13 years were bronchiolitis, wheezing crisis, correction of congenital crooked foot, fever without localizing signs with hypothesis of sepsis or pneumonia, diabetic ketoacidosis, pertussis, bronchopneumonia, and epilepsy.

In the segment Family Assessment, the records from the instruments showed a clear description of the purpose or reason for the family interview in all guides, indicating that, in nine situations, the novice nurse started the interview due to the long stay of the child and the family in the service, and/ or observing the family behavior suggesting that they could be nervous, worried, tired, anxious, or distressed. In seven circumstances, the novice nurse started the interview after some information about the family provided by another nurse or member of the nursing staff in the service indicated interpersonal conflict among the family members or between the family and the health professionals, or the nurse perceived tired or distressed family members.

All instruments had notes about the family members and staff present during the interview. Regarding family members, the child's mother alone participated in eight situations, both the father and the mother in two situations, the grandmother in two, the father alone in one situation. The aunt and her boyfriend participated in one interview, the mother and the aunt together in one interview, and one interview had the participation of the child's mother, father, and older brother. The family members interviewed were aged 16 to 50 years. Regarding the team members, in all cases the novice nurse was alone during the application of the instruments.

The segment Family Assessment also oversees the genogram development and description, in one field, of problems or concerns, strong points, and support/resources of the family. The records indicated that the genograms were correctly developed in all cases. Additional information noted for the genogram, whose description is recommended for easy visualization of the aspects related to the instrumental and expressive functioning of the family, were observed in all 16 instruments, including data related to the professions, occupations, and relationships of family members, and between them and the supporting service.

The main family problems or concerns recorded by the novice nurse referred to the lack of more detailed information about the disease, treatment and discharge, concern of the families about the other children who stayed at home, anguish about the 
delayed transfer of the child to the hospitalization unit, and the possibility of the child's being transferred to another hospital.

The strong points of the family were observed and recorded by the nurse: affectionate mother with the child; couple with close bond; and the extended family as a powerful supporting network for the child/family. The elements supporting the families were: religion; neighbors; the health network-outpatient clinic, Basic Health Unit (BHU) and hospital-school; daycare center; and extended family members such as grandparents and uncles of the child.

The last element in the segment Family Assessment referred to two questions to the family with the aim of indicating the main need of the family (related to the current disease/ hospitalization condition), as exemplified in Chart 1.

Regarding the question "If you could have a question answered in our talk, what would it be?" the notes indicated that only two families did not ask questions. The analysis of the other questions indicated that families needed to receive more detailed information about the disease, hospitalization, and/or treatment of the child.

Regarding the question "What would help you better deal with this situation?" 11 records showed the answers to this question were connected with the answers provided to the previous question, confirming that most families needed detailed information. However, seven records indicated that the family did not know how to answer this question. According to the answers provided to the previous question, such an absence of answer may relate to the fact that the family still needs to understand what is happening, or what will happen with the child in the emergency service, or the novice nurse was not able to formulate the question to the family so that they could express their ideas.

The same lack of ability was observed in the exploration of the family demands regarding the disease/hospitalization's impact on family life, showing that it is complex for a novice nurse to explore answers for each family. For instance, when a child's mother asks "When will my daughter be discharged?" the nurse could have explored this feeling better, trying to understand what makes the mother ask this question.

In the segment Actions Performed, the records indicated that the nurse's conduct was associated with the needs of the families that were raised by her during the interviews. In total, 97 actions performed by the nurse in the 16 filled instruments were checked. The most frequent actions performed by the novice nurse were "I explained the reason for the interview" (16 times), "I validated or normalized emotional answers" (16 times), "I provided the information the family needed" (15 times), and "I praised the strong points of the family" (15 times).

"I encouraged rest" (10 times), "I encouraged family support" (nine times), "I promoted communication among family members" (seven times), and "I asked the family how they would like to be involved in patient care" (one time) were the less frequent actions performed by the nurse. "I helped the family plan rituals" and "I set goals with the family" were actions not performed by the novice nurse.

Chart 2 shows the most frequent actions performed by the novice nurse, with examples related to the respective actions performed.
Chart 1 - Examples of records from the answers in the Family Care Guide for Nursing Clinical Practice to identify the main family need

\begin{tabular}{|c|l|l|}
\hline ID* & $\begin{array}{l}\text { If you could have a } \\
\text { question answered in our } \\
\text { talk, what would it be? }\end{array}$ & $\begin{array}{l}\text { What would help you better } \\
\text { deal with this situation? }\end{array}$ \\
\hline 1 & $\begin{array}{l}\text { "Can my daughter be } \\
\text { hospitalized here?" }\end{array}$ & $\begin{array}{l}\text { "Have my child hospitalized } \\
\text { here in the UH**, because it } \\
\text { is near my house." }\end{array}$ \\
\hline 9 & $\begin{array}{l}\text { "Why isn't my child } \\
\text { going to be hospitalized } \\
\text { as he is already here?" }\end{array}$ & $\begin{array}{l}\text { "I want the doctors to tell me } \\
\text { if my son will be hospitalized } \\
\text { or not." }\end{array}$ \\
\hline 10 & $\begin{array}{l}\text { "Why does he always } \\
\text { have a cold?" }\end{array}$ & $\begin{array}{l}\text { "I'd like to go back to my city in } \\
\text { has so much dust. I'm sure that } \\
\text { leaving São Paulo will improve } \\
\text { my children's health." }\end{array}$ \\
\hline 11 & $\begin{array}{l}\text { "Is this disease caused } \\
\text { by a virus going to take } \\
\text { a long time to heal?" }\end{array}$ & $\begin{array}{l}\text { "I'd like to understand how } \\
\text { long my son will stay here and } \\
\text { whether he's going to keep } \\
\text { inhaling saline solution only." }\end{array}$ \\
\hline $\begin{array}{l}\text { "Have we done } \\
\text { treatment?" }\end{array}$ & $\begin{array}{l}\text { "Hospitalizing him (the son) } \\
\text { will be good because then } \\
\text { we'll be able to find out what } \\
\text { happened to him." }\end{array}$ \\
\hline
\end{tabular}

Notes: *ID - instrument identification, according to the order of interviews; **UH - University Hospital.

Chart 2 - Most frequent actions performed by the novice nurse

\begin{tabular}{|l|l|l|}
\hline $\begin{array}{c}\text { Actions } \\
\text { performed }\end{array}$ & N & \multicolumn{1}{c|}{ Exemplos } \\
\hline $\begin{array}{l}\text { I explained the } \\
\text { reason for the } \\
\text { interview. }\end{array}$ & 16 & $\begin{array}{l}\text { ID* 9. "I've noticed you are worried } \\
\text { (mother), I'd like to talk to you to see } \\
\text { how I can help you." }\end{array}$ \\
\hline $\begin{array}{l}\text { I validated or } \\
\text { normalized } \\
\text { emotional } \\
\text { answers. }\end{array}$ & 16 & $\begin{array}{l}\text { ID 15. The mother believes the } \\
\text { health professionals do not trust her } \\
\text { description of facts; I've noticed she is } \\
\text { nervous. I establish a therapeutic talk. }\end{array}$ \\
\hline $\begin{array}{l}\text { I provided the } \\
\text { information the } \\
\text { family needed. }\end{array}$ & 15 & $\begin{array}{l}\text { ID 11. The family asks whether the } \\
\text { child's infection caused by the respiratory } \\
\text { syncytial virus (RSV) will take long to heal. } \\
\text { l explain the typical course of the infection } \\
\text { caused by the RSV. }\end{array}$ \\
\hline $\begin{array}{l}\text { I praised the } \\
\text { strong points of } \\
\text { the family. }\end{array}$ & 15 & $\begin{array}{l}\text { ID 7. The grandmother is the main } \\
\text { caregiver of the child, and she takes } \\
\text { care of three other grandchildren and a } \\
\text { teenage son. She looked worried; she is } \\
\text { affectionate with the child. I praised her } \\
\text { attention to the child and highlight its } \\
\text { importance as a family pillar. }\end{array}$ \\
\hline
\end{tabular}

Notes: ${ }^{a}$ Actions from the checklist of the Family Care Guide for Nursing Clinical Practice; *ID: instrument identification, according to the order of the interviews. 
As a consequence of the actions performed, the information contained in the segment of Observed/Reached Results indicates that the novice nurse identified the calmest and least worried families, reporting their gratitude and a better understanding of the child's hospitalization situation after the interview. The nurse also indicated the creation of bonds with the families and their recognition of the nurse as a professional to whom to report their needs.

The field for other actions performed not included in the checklist had the following information: conversation with the medical team to provide information about the disease, treatment, and discharge; conversation with the social worker to guide the family by providing information about their rights during the hospitalization period; encouraging the family talk and promoting comfort to the mother; offering conditions for personal hygiene.

When correlating the analysis of content from the Guides to the reference analysis of "development of skills for family nursing interviews"(5), the following results were obtained:

1. In the engagement stage, all 16 interviews started with the genogram development, the purpose of the interview was explained to every family, and more than one family member was present in the interviews in agreement with the perceptual, conceptual, and executive skills required in this stage of the interview, showing that the novice nurse practiced executive skills when establishing and keeping a therapeutic relationship with the families. However, it showed an absence of perceptual/conceptual skills that a family member was better understood in the family context, because when more than one family member was present, the records indicated that the interviews were conducted with only one family member.

2. In the assessment stage, perceptual/conceptual and executive skills were identified related to the exploration of the structural, developmental, and functional components of the families. However, the absence of records about a problem from the perspective of different family members, and the relationship between the problem experienced and family functioning may indicate a lack of perceptual/conceptual skills regarding some aspects of the assessment stage. In the assessment stage, it is critical to improve the executive skill for asking questions that expand the focus beyond the disease, that is, questions from the nurse that make the family think and talk about aspects related to the family system and the disease/hospitalization situation.

3. In the intervention stage, the main conceptual/perceptual skill identified was the recognition that the lack of information of an educational nature could create challenges for the families to solve their problems. The actions resulting from this skill triggered other actions-executive skills-that fulfilled the families' need for information. Other actions were performed targeting the cognitive, affective, and behavioral domains of the family. However, there was no executive skill to perform actions that actually involved the family, because the actions were performed for the family and not with the family. Thus, the lack of skills to plan tasks with the families, with the aim of family functioning, showed that the novice nurse failed to perform actions that reflected the perception of the family as a system.

Chart 3 - Correlation of perceptual, conceptual and executive skills for family interviews to the actions performed by the novice nurse

\begin{tabular}{|c|c|}
\hline $\begin{array}{l}\text { Actions performed during } \\
\text { the interviews }\end{array}$ & Correlation to skills ${ }^{\mathrm{a}}$ \\
\hline $\begin{array}{l}\text { 1. Engagement stage } \\
\text { - genograms were correctly } \\
\text { developed } \\
\text { - the purpose of the interview } \\
\text { was explained to every family } \\
\text { - members of the families } \\
\text { were invited to participate in } \\
\text { the interviews }\end{array}$ & $\begin{array}{l}\text { Presence of perceptual, } \\
\text { conceptual, and executive } \\
\text { skills related to establishing } \\
\text { and maintaining a therapeutic } \\
\text { relationship with the families. }\end{array}$ \\
\hline $\begin{array}{l}\text { - the interviews were } \\
\text { conducted with only one } \\
\text { family member }\end{array}$ & $\begin{array}{l}\text { The perceptive/conceptual skill } \\
\text { that a family member is better } \\
\text { understood in the family context } \\
\text { has to be improved even when } \\
\text { only one family member is } \\
\text { present. }\end{array}$ \\
\hline $\begin{array}{l}\text { 2. Assessment stage } \\
\text { - the structural, } \\
\text { developmental, and } \\
\text { functional components } \\
\text { of families were explored } \\
\text { with the development of } \\
\text { genograms }\end{array}$ & $\begin{array}{l}\text { There is a need for the presence } \\
\text { of perceptual/conceptual } \\
\text { and executive skills in this } \\
\text { assessment segment. }\end{array}$ \\
\hline $\begin{array}{l}\text { - lack of records on the } \\
\text { problem presented from } \\
\text { the perspective of different } \\
\text { family members. }\end{array}$ & $\begin{array}{l}\text { There is a lack of perceptual/ } \\
\text { conceptual and executive skills } \\
\text { to explore the perception of the } \\
\text { problem/concern by different } \\
\text { family members. } \\
\text { There is an absence of questions } \\
\text { that expand the focus beyond the } \\
\text { disease. }\end{array}$ \\
\hline $\begin{array}{l}\text { 3. Intervention stage } \\
\text { - information was provided } \\
\text { according to the needs of } \\
\text { the families }\end{array}$ & $\begin{array}{l}\text { There is a need for the presence } \\
\text { of perceptual/conceptual skill } \\
\text { to recognize that the lack of } \\
\text { information of educational nature } \\
\text { can inhibit the problem-solving } \\
\text { skills of the family. }\end{array}$ \\
\hline $\begin{array}{l}\text { - the actions were } \\
\text { conducted for the family, } \\
\text { and not with the family }\end{array}$ & $\begin{array}{l}\text { There is a lack of executive skill } \\
\text { to perform actions that actually } \\
\text { involve the family in the planning } \\
\text { and execution of actions. }\end{array}$ \\
\hline
\end{tabular}

Note: aAs described by Wright and Leahey (2012).

\section{DISCUSSION}

From the records in the guides, it is possible to conclude that the novice nurse presented the required perceptual, conceptual, and executive skills to conduct interviews with families, though indicating aspects that still need to be improved in the skills. 
The Guide, along with the previous training on family nursing, favored the development or improvement of such skills.

A study conducted in Hong Kong showed that nursing undergraduates who received training on the Calgary Family Assessment Model thought they were better prepared and with fewer problems in performing the assessment of families after the course when compared to a group of nurses without this training(9).

In agreement with this, the literature shows that the acquisition of skills when working with families is enhanced by a process that requires the association of the theory of family nursing concepts with the clinical practice of nurses, requires the supervision and support of an experienced professional on this theme, and needs feedback about the actions performed, which in turn allows nurses to think about their performance and consolidate the skills acquired ${ }^{(10-15)}$.

Like this study, other studies show that using different pedagogical strategies during nurse training, such as role play involving situations with families, case studies and discussions, teaching of interview skills, reflective practices and communication training, provides the development of perceptual, conceptual, and executive skills to work with families ${ }^{(9,13,16)}$.

The interviews conducted in this study through the Guide lasted 15 minutes on average, indicating that it is possible to perform family assessment and interventions in a short time and in a context as unusual as the emergency service. In agreement with this finding, a study showed that family interviews that lasted 15 minutes on average can be proper tools to ensure nurse involvement with families and their histories, which in turn allows family assessment and interventions ${ }^{(12)}$.

The novice nurse developed perceptual, conceptual, and executive skills for family interviews, especially regarding structural and functional assessments, because the developed genograms provided relevant information about the families. Studies show that nurses consider genograms an important element for patient care, as they provide concrete information about families ${ }^{(12,17)}$.

The Guide directed the communication between the novice nurse and the family, as well as the structural and functional assessment of the families. Studies show that family nursing training for nurses that teach intervention methods and skill development lead to positive attitudes on the part of these professionals, especially because they recognize the family as a care provision unit and support the improvement of skills, such as interpersonal communication and the ability to evaluate the family functioning ${ }^{(10,12,14)}$.

Another perceptive and conceptual skill observed in this study refers to the fact that the novice nurse conducted the interviews seeking to understand the main needs of families, supported by two questions to the families for this purpose. As explained in another study, this type of question allows the nurse to act according to the main need reported by the family ${ }^{(18)}$.

Despite the presence of most essential skills, the results of this study showed that it was difficult for a novice nurse to connect family problems or needs related to the disease and hospitalization with aspects related to structural and functional assessment. The skill of asking questions to help understand the problem and explore the different viewpoints of family members still needs to be improved in this stage of professional development.
A study showed that novice nurses who are still improving their family interview skills face challenges in collecting and processing data in a coherent and effective way; therefore, the data collected are often not useful to explain the real need of the family ${ }^{(19)}$. What distinguishes a novice nurse from an expert nurse is the ability to recognize the relevant aspects of a situation, proposing effective interventions. An expert nurse understands the situations, identifies the problems, and performs direct interventions, which is still incipient in a novice nurse ${ }^{(4)}$.

The action of praising the family's strong points was an executive skill developed by the novice nurse and refers to a paradigm shift, because nurses are routinely trained to look only at problems, and not at the strong points of families ${ }^{(20)}$. The novice nurse also performed other actions related to the affective and behavioral domains, showing that a novice nurse can perform effective interventions with families.

The provision of information to families, according to the needs reported by them, was one of the executive skills often performed by the novice nurse, showing that perceptual and conceptual skills were developed regarding this component. The action of providing information started when the nurse indicated an availability to talk to the families. According to a study, establishing communication based on the provision of information as an element that provides care is equivalent to providing emotional support to families ${ }^{(2)}$.

Regarding the use of a guide to support the process of skill acquisition by the novice nurse in the family nursing field, a Canadian study that explored the perspectives of students, professors, and former students of a nursing school about the integration of family nursing training and family assessment skills into clinical practice showed that nurses believe that using formal tools for family assessment is essential for the development of family nursing knowledge ${ }^{(17)}$.

Despite the knowledge about the importance of family nursing training, the literature does not have a standardized language to describe the actions performed with families, nor documentation of systematized work with families. Studies suggest training for nurses on how to document the actions performed with families to ensure better visibility of the work developed with families ${ }^{(10,17)}$.

Finally, the Guide used to conduct and record the interviews in this study is aligned with the suggestions found in the literature, as it is considered an innovative and effective tool not only for the development of the skills in novice nurses, but also to systematize and document the work developed with families.

\section{Study limitations}

One study limitation refers to the fact that the interviews were conducted by only one novice nurse, in only one care provision center.

\section{Contributions to the nursing field}

This study presents an instrument that can be used in nursing practice, training, or research. When associated with learning processes in the area of family nursing, this instrument can promote the development of essential skills for nurses to conduct family interviews and, when combined with care provision, it 
acts as a facilitator and a guide to families in clinical practice. A secondary contribution is that the results of this study indicate the main needs of families seen in children's emergency services and the actions performed to fulfill each need.

\section{FINAL CONSIDERATIONS}

Considering that in order to provide care to families in clinical practice, a novice nurse needs to acquire specific skills for the interview process, the Family Care Guide for Nursing Clinical Practice has proved to be a supporting strategy in this area, allowing nurse development for clinical skill acquisition to work with families. Skill acquisition and consolidation by the novice nurse were the result of an educational intervention process comprised of theory and practice, which included a family interview guide and the support of an expert nurse, who acted as a mentor in the learning process.

The incorporation and understanding of perceptual, conceptual, and executive skills by novice nurses when conducting family interviews requires the participation of a mentor in the development process, allowing both expert and novice nurses to discuss the intersection between theory and practice, leading to a reflexive practice, essential for the improvement of more advanced skills.

The Family Care Guide for Nursing Clinical Practice is a useful tool to guide training and continuing education processes, collaborate in the development of skills in novice nurses to conduct family interviews, and enable the cognitive consolidation of essential elements of patient- and familycentered care.

\section{REFERENCES}

1. Collet N. Interacting subjects in hospitalized children care: challenges for Pediatric Nursing. Rev Bras Enferm[Internet]. 2012[cited 2016 Oct 15];65(1):7-8. Available from: http://www.scielo.br/pdf/reben/v65n1/en_01.pdf

2. Foster M, Whitehead L, Maybee P. The parents', hospitalized child's, and health care providers' perceptions and experiences of family-centered care within a pediatric critical care setting: a synthesis of quantitative research. J Fam Nurs[Internet]. 2015[cited 2016 Oct 15];22(1):6-73. Available from: https://www.ncbi.nlm.nih.gov/pubmed/23884697

3. Angelo M, Cruz AC, Mekitarian FF, Santos CC, Martinho MJ, Martins MM. Nurses' attitudes regarding the importance of families in pediatric nursing care. Rev Esc Enferm USP[Internet]. 2014[cited 2016 Oct 15];48(No.Spe):74-9. Available from: http://www. scielo.br/pdf/reeusp/v48nspe/0080-6234-reeusp-48-esp-075.pdf

4. Benner P. From novice to expert: excellence and power in clinical nursingpractice. New Jersey: Prentice Hall; 2001.

5. Wright LM, Leahey M. Enfermeiras e Famílias: um guia para avaliação e intervenção na família. São Paulo: Roca; 2012.

6. Angelo M, Cruz AC. Autoeficácia do enfermeiro para o relacionamento com a família. Rev Ref. 2015;3(IV):151-5.

7. Cruz AC. Relacionamento com famílias na prática clínica de enfermagem no contexto neonatal e pediátrico: impacto de uma intervenção educativa e proposição de uma escala de autoeficácia.[Tese]. São Paulo: Universidade de São Paulo; Escola de Enfermagem. 2015.

8. Yin RK. Estudo de caso: planejamento e métodos. Porto Alegre: Bookman; 2015. 320 p.

9. Lee AC, Leung SO, Lingchan PS, Chung JO. Perceived level of knowledge and difficulty in applying family assessment among senior undergraduate nursing students. J Fam Nurs. 2010;16(2):177-95.

10. Duhamel F, Dupuis F, Turcotte A, Martinez AM, Goudreau J. Integrating the Illness Beliefs Model in clinical practice: a Family Systems Nursing knowledge utilization model. J Fam Nurs[Internet]. 2015[cited 2016 Oct 15];21(2):322-48. Available from: https://www.ncbi.nlm.nih.gov/pubmed/25838467

11. Blondal K, Zoega S, Hafsteinsdottir JE, Olafsdottir OA, Thorvardardottir AB, Hafsteinsdottir SA, et al. Attitudes of Registered and Licensed Practical Nurses About the Importance of Families in Surgical Hospital Units: Findings From the Landspitali University Hospital Family Nursing Implementation Project. J Fam Nurs[Internet]. 2014[cited 2016 Oct 15];20(3):355-75. Available from: http://journals.sagepub.com/doi/abs/10.1177/1474515116663143

12. Holtslander L, Solar J, Smith NR. The 15-Minute Family Interview as a learning strategy for senior undergraduate nursing students. J Fam Nurs[Internet]. 2013[cited 2016 Oct 15];19(2):230-48. Available from: http://journals.sagepub.com/doi/abs/10.1177/1074840712472554

13. Leahey $M$, Harper-Jaques S. Integrating family nursing into a mental health urgent care practice framework: ladders for learning. J Fam Nurs[Internet]. 2010[cited 2016Oct 15];16(2):196-212. Availablefrom: http://journals.sagepub.com/doi/abs/10.1177/1074840710365500

14. Anderson KH, Friedemann ML. Strategies to teach family assessment and intervention through an online international curriculum. J Fam Nurs[Internet]. 2010[cited 2016 Oct 15];16(2):213-33. Available from: http://journals.sagepub.com/doi/abs/10.1177/1074840710367639

15. Binding LL, Morck AC, Moules NJ. Learning to see the other: a vehicle of reflection. Nurse Educ Today[Internet]. 2010 [cited 2016 Oct 15];30(6):591-4. Available from: https://www.ncbi.nlm.nih.gov/pubmed/20071058

16. Flowers KA, John WS, Bell JM. The role of the clinical laboratory in teaching and learning family nursing skills. J Fam Nurs[Internet]. 2008[cited 2016 Oct 15];14(2):242-67. Available from: http://journals.sagepub.com/doi/abs/10.1177/1074840708316562

17. St John W, Flowers K. Working with families: from theory to clinical nursing practice. Collegian[Internet]. 2009 [cited 2016 Oct 
15];16(3):131-8. Available from: https://www.ncbi.nlm.nih.gov/pubmed/19831146

18. Duhamel F, Dupuis F, Wright L. Families' and nurses' responses to the "One Question Question": reflections for clinical practice, education, and research in family nursing. J Fam Nurs[Internet]. 2009[cited 2016 Oct 15];15(4):461-85. Available from: http:// journals.sagepub.com/doi/abs/10.1177/1074840709350606

19. Eggenberger SK, Regan M. Expanding simulation to teach family nursing. J Nurs Educ[Internet]. 2010[cited 2016 Oct 15];49(10):5508. Available from: https://www.ncbi.nlm.nih.gov/pubmed/20672781

20. Bell JM. Family Systems Nursing: re-examined. J Fam Nurs[Internet]. 2009[Internet]. 15(2):123-9. Available from: https://www. ncbi.nlm.nih.gov/pubmed/19423766 